\title{
Rehabilitacja zawodowa w warsztatach terapii zajęciowej i zakładach aktywizacji zawodowej - realizacja czy jej brak?
}

\author{
Vocational rehabilitation in occupational therapy workshops \\ and vocational development centres - implementation or its \\ absence?
}

\section{Streszczenie:}

Uczestnictwo osób z niepełnosprawnością intelektualną w zajęciach w warsztacie terapii zajęciowej (WTZ) lub praca w zakładzie aktywności zawodowej (ZAZ) ma na celu przygotowanie do wejścia na rynek pracy. Zadaniem wyżej wymienionych placówek, oprócz realizacji procesu rehabilitacji społecznej, czyli przysposobienia do pełnienia ról społecznych, pobudzania aktywności społecznej i współpracy z innymi ludźmi, jest prowadzenie rehabilitacji zawodowej, która umożliwia nabycie umiejętności związanych z wykonywanym zawodem lub pracą. Zawarte w prezentowanym artykule zagadnienia dotyczą specyfiki sposobów i skuteczności realizacji rehabilitacji zawodowej w warsztacie terapii zajęciowej i zakładzie aktywności zawodowej. Słowa kluczowe: rehabilitacja zawodowa, warsztat terapii zajęciowej, zakład aktywności zawodowej, niepełnosprawność intelektualna

\section{Abstract:}

The aim of participation of people with intellectual disabilities in activities in an occupational therapy workshop (OTW) or work in a vocational de- 
Mateusz Szafrański - Rehabilitacja zawodowa...

velopment centre (VDC) is preparing them to enter in the labour market. Apart from implementing the process of social rehabilitation, that is preparation for fulfilling social roles, stimulation of a social activity and cooperation with other people, the task of the above-mentioned institutions is to conduct a vocational rehabilitation which enables people with intellectual disabilities to acquire skills related to their occupation or job. Issues contained in this article concern the specificity of manners and the effectiveness of the implementation of vocational rehabilitation in the vocational therapy workshop and vocational activation centre.

Keywords: vocational rehabilitation, occupational therapy workshop, vocational development centre, intellectual disability

\section{Wprowadzenie}

Uczestnictwo osoby z niepełnosprawnością intelektualną w zajęciach w warsztacie terapii zajęciowej (WTZ) lub praca w zakładzie aktywności zawodowej (ZAZ) stanowi etap przejściowy, który ma przygotowywać jednostkę do zatrudnienia na chronionym lub otwartym rynku pracy. Katarzyna Ćwirynkało pisze, że „osiągnięcie tego celu prowadzić będzie ku pełniejszej integracji zawodowej i społecznej”1. Do jednego z celów tych instytucji należy aktywizacja zawodowa osób z niepełnosprawnością. Obie placówki realizują w większym stopniu proces rehabilitacji społecznej, który stanowi przygotowanie do pełnienia ról społecznych, współpracę z innymi ludźmi czy kształtowanie zaradności osobistej i pobudzanie aktywności społecznej. Posiadanie umiejętności społecznych jest niezbędne do wypełniania ról zawodowych, jednak konieczne jest także posiadanie umiejętności związanych bezpośrednio $\mathrm{z}$ wykonywanym zawodem lub pracą. $\mathrm{W}$ artykule autor zwraca uwagę na fakt, że w zakładach aktywności zawodowej proces rehabilitacji zawodowej nie jest w pełni realizowany, zaś w warsztatach terapii zajęciowej ten rodzaj rehabilitacji nie występuje.

\footnotetext{
${ }^{1}$ K. Ćwirynkało, Osoby z głębszq niepełnosprawnościq intelektualnq, [w:] Rehabilitacja $i$ edukacja osób z niepełnosprawnościq wielozakresowq, K. Ćwirynkało, C. Kosakowski (red.), Toruń 2012, s. 236.
} 


\section{Człowiek z niepełnosprawnością intelektualną}

Według Ustawy o rehabilitacji zawodowej i społecznej oraz zatrudnianiu osób niepełnosprawnych z dnia 27 sierpnia 1997 roku „niepełnosprawnymi są osoby, których stan fizyczny, psychiczny lub umysłowy trwale lub okresowo utrudnia, ogranicza bądź uniemożliwia wypełnianie ról społecznych, a w szczególności ogranicza zdolności do wykonywania pracy zawodowej" (Dz. U. Nr 123, poz. 776). Definicja konkretnie wskazuje na aspekt zatrudnienia osób z niepełnosprawnością, co jest kluczowym zagadnieniem w artykule. Najnowszą definicję niepełnosprawności intelektualnej z roku 2015 prezentuje publikacja pod redakcją naukową wydania polskiego Piotra Gałeckiego i Łukasza Święcickiego „Kryteria Diagnostyczne z DSM-5 Desk Reference”. Według powyższego źródła „niepełnosprawność intelektualna jest zaburzeniem rozpoczynającym się w okresie rozwoju i obejmuje deficyty zarówno w zakresie funkcjonowania intelektualnego, jak i adaptacyjnego $w$ obszarach dotyczących rozumienia pojęć, funkcjonowania społecznego oraz w dziedzinach praktycznych"3. Deficyty wskazane $\mathrm{w}$ definicji nie są tożsame $\mathrm{z}$ biernością zawodową osób z niepełnosprawnością intelektualną. Sfery te mogą być zaburzone, ale dzięki wsparciu innych osób lub instytucji wcale nie muszą wykluczać z rynku pracy. Poniższa tabela przedstawia możliwości i predyspozycje osób z niepełnosprawnością intelektualną w stopniu lekkim, umiarkowanym i znacznym podczas podejmowania aktywności zawodowej. Celowo pominięto głęboki stopień niepełnosprawności intelektualnej. Osoby z tym rodzajem i stopniem niepełnosprawności nie są uczestnikami warsztatów terapii zajęciowej, ani zakładów aktywności zawodowej. 2015.

2 P. Gałecki, Ł. Święcicki, Kryteria diagnostyczne z DSM-5. Desk Reference, Wrocław 3 Ibid., s. 15. 
Mateusz Szafrański - Rehabilitacja zawodowa...

Tabela. 1. Możliwości i predyspozycje osoby z niepełnosprawnością intelektualną w podejmowaniu aktywności zawodowej

\begin{tabular}{|l|l|}
\cline { 2 - 3 } \multicolumn{1}{c|}{} & \multicolumn{1}{c|}{$\begin{array}{c}\text { MOŻLIWOŚCI I PREDYSPOZYCJE OSOBY } \\
\text { Z NIEPEENOSPRAWNOŚCIĄ INTELEKTUALNĄ (NI) } \\
\text { W PODEJMOWANIU AKTYWNOŚCI ZAWODOWEJ }\end{array}$} \\
\hline $\begin{array}{l}\text { LEKKI } \\
\text { stopień NI }\end{array}$ & $\begin{array}{l}\text { Dorośli mogą znaleźć zatrudnienie, które nie wymaga } \\
\text { szczególnych umiejętności konceptualnych, czyli m.in. } \\
\text { umiejętności planowania, tworzenia strategii, ustalania } \\
\text { priorytetów, posługiwania się pieniędzmi. Często osoby } \\
\text { wymagają pomocy w podjęciu decyzji dotyczącej nauki } \\
\text { zawodu i aktywności zawodowej. }\end{array}$ \\
\hline $\begin{array}{l}\text { UMIARKOWANY } \\
\text { stopień NI }\end{array}$ & $\begin{array}{l}\text { Dorośli potrzebują pomocy we wszystkich czynnościach } \\
\text { zawodowych, które wymagają wysokiego poziomu } \\
\text { umiejętności szkolnych (czytanie, pisanie, rozumienie } \\
\text { pojęć czasu i pieniądza). Mogą znaleźć zatrudnienie } \\
\text { wymagające niskich umiejętności ze sfery pojęciowej } \\
\text { jedynie przy wsparciu współpracowników i osób kon- } \\
\text { trolujących. W pracy zawodowej pracownikom potrzebne } \\
\text { jest wsparcie w zakresie komunikacji i umiejętności } \\
\text { społecznych w celu osiągnięcia sukcesu. }\end{array}$ \\
\hline $\begin{array}{l}\text { ZNACZNY } \\
\text { stopień NI }\end{array}$ & $\begin{array}{l}\text { Dorośli rzadko podejmują decyzje, w tym zawodowe. Ich } \\
\text { umiejętności ze sfery pojęciowej są znacznie ograniczone, } \\
\text { co często uniemożliwia wykonywanie pracy. Mogą nabyć } \\
\text { te umiejętności, jednak wymagają długotrwałego uczenia } \\
\text { się i ciągłego wsparcia. }\end{array}$ \\
\hline
\end{tabular}

Źródło: opracowanie własne na podstawie: P. Gałecki, Ł. Święcicki, Kryteria diagnostyczne z DSM-5. Desk Reference, Wrocław 2015, s. 17-19.

Z tabeli wynika, że zatrudnienie mogą najczęściej podejmować osoby z lekkim i umiarkowanym stopniem niepełnosprawności intelektualnej. Natomiast osoby ze znacznym stopniem są rzadziej zatrudniane. Osoby z głębokim stopniem w ogóle nie podejmują aktywności zawodowej. Maciej Zegarek reasumuje, że „możliwości zatrudnienia osób niepełnosprawnych determinowane są przez orzeczony stopień niepełnosprawności bezpośrednio związany z rodzajem niepełnosprawności i zakresem ograniczeń wynikających z dysfunkcji organi- 
zmu, a także przez rodzaj i poziom posiadanych kwalifikacji i stopień osobistej aktywności w poszukiwaniu pracy ${ }^{4}$. Dla lekkiego, umiarkowanego i znacznego stopnia niepełnosprawności intelektualnej przewiduje się realizację procesu rehabilitacji zawodowej, dzięki której kształtowane są umiejętności zawodowe, umożliwiające zatrudnienie. Osoby $\mathrm{z}$ głębokim stopniem niepełnosprawności intelektualnej nie podlegają temu procesowi. Według M. Zegarka może to być zatrudnienie na otwartym rynku pracy dla osób z lekkim stopniem niepełnosprawności, w warunkach pracy chronionej dla osób z umiarkowanym bądź znacznym stopniem niepełnosprawności i w zakładach aktywności zawodowej dla osób ze znacznym stopniem niepełnosprawności lub umiarkowanym ze współwystępującymi zaburzeniami, np. autyzmem ${ }^{5}$. Zanim jednak osoba $\mathrm{z}$ niepełnosprawnością podejmie pracę, ma możliwość uczestnictwa w zajęciach $\mathrm{w}$ warsztacie terapii zajęciowej, gdzie kształtowane są jej umiejętności społeczne i zawodowe niezbędne w pracy.

\section{Rehabilitacja zawodowa}

Zdaniem Marcina Garbata rehabilitacja zawodowa umożliwia powrót do czynnej działalności osoby z niepełnosprawnością, która tę zdolność utraciła lub jej nie posiadała ${ }^{6}$. Celem rehabilitacji zawodowej według Międzynarodowej Organizacji Pracy jest umożliwienie osobie z niepełnosprawnością uzyskanie pracy, utrzymanie jej i awans, dzięki udzielaniu podmiotowi usług poradnictwa zawodowego, szkolenia za-

${ }^{4}$ M. Zegarek, Rola doradcy zawodowego w procesie rehabilitacji zawodowej osób niepetnosprawnych, [w:] A. Kalbarczyk, B. Ławniczak, G. Magnuszewska-Otulak, M. Zegarek, Poradnictwo zawodowe dla osób niepetnosprawnych, Wyd. MPiPS, Warszawa 2009, s. 139.

5 Ibid., s. 140.

6 M. Garbat, Praca dla osób z niepetnosprawnościami - wartość, rehabilitacja czy konieczność?, [w:] Labor czy opus? Socjopedagogiczne konteksty ludzkiej pracy, A. Dobrychłop, E. Kowalska, P. Prüfer (red.), Zielona Góra 2012, s. 197. 
Mateusz Szafrański - Rehabilitacja zawodowa...

wodowego i zatrudnienia7. Stanisław Kowalik wyróżnia pięć etapów rehabilitacji zawodowej. Pierwszym z nich jest aktywizacja przedprodukcyjna, np. terapia zajęciowa. Drugim pełna diagnoza zawodowego potencjału rehabilitacyjnego, czyli rozpoznanie potencjału psychicznego i fizycznego osoby z niepełnosprawnością oraz zapobieganie zagrożeniom, które mogą wystąpić po podjęciu działań. Trzeci etap to przygotowanie do pracy, poprzez kształcenie zawodowe. Następnie następuje dostosowanie stanowiska pracy dla pracownika z niepełnosprawnością. Ostatnim etapem jest zatrudnienie i doskonalenie zawodowe na otwartym rynku pracy8. S. Kowalik ujmuje rehabilitację zawodową kompleksowo. Rehabilitacja zawodowa umożliwia klientowi całościowe przygotowanie do pełnienia ról zawodowych na rynku pracy. Rozpoczyna się od udziału w terapii zajęciowej, dzięki której osoba nabywa podstawowe umiejętności niezbędne do pracy, a kończy zatrudnieniem $\mathrm{w}$ warunkach pracy tożsamych dla pełnosprawnych konkurentów.

\section{Uczestnik warsztatu terapii zajęciowej}

Polską instytucją, która realizuje proces rehabilitacji zawodowej osób z niepełnosprawnością są warsztaty terapii zajęciowej (WTZ). Dotychczas utworzono ich 6849. W Ustawie z dnia 9 maja 1991 roku o zatrudnianiu i rehabilitacji zawodowej osób niepełnosprawnych następująco definiuje się funkcję WTZ. „Oznacza to zorganizowane w zakładzie pracy stanowiska umożliwiające prowadzenie rehabilitacji przez terapię zajęciową dla osób niepełnosprawnych z upośledzeniem uniemożliwiającym podjęcie pracy zarobkowej, stanowiące wyodręb-

7 T. Majewski, MOP $w$ działaniach na rzecz rehabilitacji zawodowej i zatrudnienia osób niepełnosprawnych. Niepełnosprawni na rynku pracy, „Biuletyn Ośrodka Informacyjnego Rady Europy" 1997, nr 4, s. 32.

8 D. Wolska, Umiejętności życiowe jako wyznacznik aktywizacji zawodowej dorosłych z głębszą niepełnosprawnościq intelektualną, Kraków 2015, s. 41-42.

9 A. Morysińska i in., Badanie sytuacji warsztatów terapii zajęciowej. Raport końcowy z badania, Warszawa 2014, s. 6. 
nioną organizacyjnie jednostkę" (Dz. U. $1991 \mathrm{Nr}$ 46, art. 3. p. 4.). W polskich aktach prawnych obowiązują również inne szczegółowe rozwiązania dotyczące działania WTZ - są nimi: Rozporządzenie Ministra Gospodarki, Pracy i Polityki Społecznej z dnia 25 marca 2004 roku w sprawie warsztatów terapii zajęciowej oraz Ustawa z dnia 27 sierpnia 1997 roku o rehabilitacji zawodowej i społecznej oraz zatrudnianiu osób niepełnosprawnych. Warsztaty terapii zajęciowej funkcjonują w Polsce w oparciu o te akty normatywne. Według Ustawy z roku 1997 „warsztat oznacza wyodrębnioną organizacyjnie i finansowo placówkę stwarzającą osobom niepełnosprawnym niezdolnym do podjęcia pracy możliwość rehabilitacji społecznej i zawodowej w zakresie pozyskania lub przywracania umiejętności niezbędnych do podjęcia zatrudnienia" (Dz. U. $1997 \mathrm{Nr} 123$ poz. 776, art. 10a). Zdaniem Tadeusza Kotta rehabilitacja zawodowa i społeczna ma się odbywać za pomocą terapii zajęciowej ${ }^{10}$. Techniki terapii zajęciowej mają poprawiać umiejętności wykonywania zadań codziennego życia oraz zaradność osobistą, a także rozwijać psychofizyczne sprawności i umiejętności zawodowe, które umożliwiłyby podjęcie pracy (Dz. U. 1997 Nr 123 poz. 776, art. 10a). Z Ustawy wynika, że „warsztaty mogą być organizowane przez fundacje, stowarzyszenia lub przez inne podmioty" (Dz. U. 1997 Nr 123 poz. 776, art. 10b). Do innych można zaliczyć gminy.

Działalność WTZ finansowana jest ze środków powiatu, na terenie którego placówka się znajduje. W momencie utworzenia WTZ koszty związane ze zwiększeniem liczby uczestników pokrywa Państwowy Fundusz Rehabilitacji Osób Niepełnosprawnych (Dz. U. 1997 Nr 123 poz. 776 , art. 10b).

Ditta Baczała wskazuje, że uczestnikami WTZ mogą być osoby, które spełniają dwa warunki. Muszą to być osoby z niepełnosprawnością intelektualną lub z innymi dysfunkcjami, np. ruchu i muszą mieć skończone 16 lat. Aby kandydat na uczestnika WTZ mógł uczestniczyć

$10 \mathrm{~T}$. Kott, Zajęcia pozalekcyjne i terapia zajęciowa z osobami o obniżonej sprawności umysłowej, Warszawa 2005, s. 125. 
Mateusz Szafrański - Rehabilitacja zawodowa...

w zajęciach na orzeczeniu wydanym przez powiatowy lub miejski zespół do spraw orzekania o niepełnosprawności powinien posiadać zapis wskazujący jego niezdolność do wykonywania pracy oraz wskazanie do udziału w terapii zajęciowejej. Zajęcia w placówce trwają 5 dni w tygodni, 7 godzin każdego dnia ${ }^{12}$. Aneta Sikorska podaje konkretne czynności w rehabilitacji zawodowej i społecznej, które realizowane są w WTZ. Wymienia m.in. „kształcenie i rozwijanie podstawowych umiejętności zawodowych w pracowniach: garncarstwa i ceramiki, gospodarstwa domowego, informatyki, zabawkarstwa; podnoszenie poziomu aktywności ruchowej (motorycznej), w takich specjalistycznych pracowniach, jak: pracownia fizykoterapii i kinezyterapii; rozwijanie swobodnej aktywności twórczej w pracowniach: malarstwa i grafiki komputerowej oraz rękodzieła i tkactwa artystycznego; rozwijanie i zdobywanie umiejętności skutecznego porozumiewania się oraz rozwiązywania sytuacji trudnych (zadania te realizowane są w pracowniach psychoterapii lub socjoterapii)"13. Prowadzenie rehabilitacji zawodowej uczestnika WTZ nie powinno pomijać wątku rehabilitacji społecznej. Obie się wzajemnie uzupełniają. Warunkiem podjęcia przez uczestnika zajęć w WTZ pracy na chronionym lub otwartym rynku jest w miarę samodzielne uczestnictwo w życiu społecznym, także w miejscu pracy. Rehabilitacja społeczna, jak wynika z Ustawy z 1997 roku, ma być realizowana po przez „wyrabianie zaradności osobistej i pobudzanie aktywności społecznej osoby niepełnosprawnej; wyrabianie umiejętności samodzielnego wypełniania ról społecznych; likwidację barier, w szczególności architektonicznych, urbanistycznych, transportowych, technicznych, w komunikowaniu się i dostępie do informacji; kształtowanie w społeczeństwie właściwych postaw i zachowań sprzyjających integracji z osobami

11 D. Baczała, Niepełnosprawność intelektualna a kompetencje społeczne, Toruń 2012, s. 119.

12 Ibid.

${ }^{13}$ A. Sikorska, Wielowymiarowa rehabilitacja osób niepełnosprawnych $w$ warsztatach terapii zajęciowej, [w:] Pedagogiczne, medyczne i ekonomiczne aspekty niepetnosprawności, R. Czepczarz, W. Duczmal, S. Śliwa (red.), Opole 2013, s. 138. 
niepełnosprawnymi" (Dz. U. 1997 Nr 123 poz. 776, art. 9). Rehabilitacja zawodowa ma z kolei ułatwić osobie z niepełnosprawnością uzyskanie i utrzymanie odpowiedniego zatrudnienia oraz awans zawodowy (Dz. U. 1997 Nr 123 poz. 776, art. 8). Ocena zdolności do pracy wymaga diagnozy (również za pomocą badań lekarskich) sprawności fizyczno-psychiczno-umysłowej niezbędnej do wykonywania zawodu, ustalenia kwalifikacji, doświadczenia zawodowego oraz zainteresowań kandydata do pracy. Konieczne jest też prowadzenie poradnictwa zawodowego, które uwzględniałoby zdolności osoby z niepełnosprawnością, wybierając odpowiedni zawód (Dz. U. 1997 Nr 123 poz. 776, art. 8). Większość placówek w Polsce nie podejmuje czynności związanych z kształtowaniem kariery zawodowej uczestników. Uczestnicy przyjmują bierną postawę. Często podczas orzekania o stopniu niepełnosprawności i zdolności do pracy osoby z niepełnosprawnością celowo zaniżają swoje umiejętności, aby nie podejmować pracy. Nie chcą opuszczać zajęć w WTZ. Innym powodem może być wpływ znaczących osób, którymi najczęściej są rodzice, nie zawsze akceptujący decyzje swoich dzieci o aktywności zawodowej. Rodzice prawdopodobnie boją się utraty kontroli nad własnym dzieckiem, mimo że jest już pełnoletnie. Rehabilitacja społeczna i zawodowa uczestników WTZ, która sprzyja przygotowaniu do podjęcia pracy, opiera się na indywidualnym programie rehabilitacji. Program uwzględnia rozwój „zaradności osobistej, samodzielności społecznej, form komunikowania się, poprawy kondycji psychicznej oraz fizycznej sprzyjającej niezależności, samodzielności i aktywności oraz radzenie sobie w trudnych sytuacjach, umiejętności wykonywania różnych czynności wynikających $\mathrm{z}$ form terapii zajęciowej, psychofizycznych sprawności niezbędnych w pracy, usprawniania ruchowego"14. Program ten musi zawierać, jak pisze A. Sikorska „orientacyjny czas trwania terapii; osoby odpowiedzialne za realizację do programu; formy współpracy z rodziną lub opiekunami; zaplecze terapii oraz organizacyjne i technicz-

14 T. Kott, Zajęcia pozalekcyjne..., op. cit., s. 125. 
ne dostosowanie do stopnia sprawności psychofizycznej uczestnika; metody opanowania czynności przyspasabiających do pracy; zakres i metody nauki zaradności osobistej i przystosowania do życia; formy rehabilitacji psychicznej i społecznej"15. Rada programowa WTZ, czyli kierownik, specjaliści z zakresu rehabilitacji, instruktorzy terapii zajęciowej, psycholog, doradca zawodowy, oceniają co najmniej raz w ciągu trzech lat realizację indywidualnego programu rehabilitacji16. Dzięki stałej ocenie uczestnika WTZ można dokonywać zmian w programie ${ }^{17}$.

Proces rehabilitacji w WTZ realizowany jest za pomocą terapii zajęciowej. Aleksandra Maciarz twierdzi, że terapia zajęciowa „to oddziaływanie terapeutyczne (rozwijające, usprawniające, usamodzielniające) poprzez organizowanie różnego rodzaju zajęć ruchowych (rytmika, taniec, gry ruchowe, sport), artystycznych (sztuki plastyczne, muzykowanie, haftowanie itd.), gospodarczych (zajęcia ogrodnicze, hodowlane, kucharskie itd.) oraz rzemieślniczych przyuczających na przykład osoby niepełnosprawne umysłowo do prac zawodowych"18. Dzięki złożonej, wielowymiarowej ofercie terapii zajęciowej uczestnik znajduje dla siebie najbardziej odpowiednią formę jej realizacji, poprzez udział w zajęciach pracowni, która jest dostosowana do jego zainteresowań i możliwości. W rzeczywistości często dzieje się inaczej. To rada programowa kwalifikuje uczestnika do konkretnej pracowni, mimo że uczestnik nie wykazuje inicjatywy bycia $w$ niej. W WTZ możliwe jest jednak zapoznanie uczestnika z ofertami innych pracowni, dzięki rotacji do nich. Ma to miejsce po wcześniejszym uzgodnieniu z instruktorem pracowni macierzystej uczestnika i instruktorem pracowni, w której zajęciach uczestnik wyraża chęć udziału.

\footnotetext{
15 A. Sikorska, Wielowymiarowa rehabilitacja osób..., op. cit., s. 140-141.

16 D. Baczała, Niepełnosprawność intelektualna..., op. cit., s. 118.

${ }^{17}$ A. Sikorska, Wielowymiarowa rehabilitacja osób..., op. cit., s. 141.

${ }^{18}$ A. Maciarz, Mały leksykon pedagoga specjalnego, Kraków 2005, s. 105.
} 
Uczestnicy WTZ otrzymują kieszonkowe w wyniku udziału w treningu ekonomicznym. Z zapisu w Rozporządzeniu Ministra Gospodarki Pracy i Polityki Społecznej z 2004 roku w sprawie warsztatów terapii zajęciowej wynika, że uczestnik „może otrzymać do swojej dyspozycji środki finansowe w wysokości nieprzekraczającej $20 \%$ minimalnego wynagrodzenia za pracę" (Rozp. MGPiPS 2004 par. 12 p. 1, Dz. U. $2004 \mathrm{Nr} 63$ poz. 587). Ich wysokość ustala rada programowa na podstawie indywidualnego programu terapii i regulaminu WTZ (Rozp. MGPiPS 2004 par. 12 p. 2, Dz. U. 2004 Nr 63 poz. 587). Osoby z niepełnosprawnością dzięki treningowi ekonomicznemu sami gospodarują swoimi pieniędzmi. Kieszonkowe stanowi dla uczestników formę samodzielnie zarobionych pieniędzy.

Prowadzona w WTZ rehabilitacja społeczna, zawodowa, psychologiczna i medyczna przyczynia się do dobrego przygotowania uczestnika z niepełnosprawnością intelektualną do pełnienia ról społecznych. Sprzyja temu wielowymiarowa, specjalistyczna terapia zajęciowa, w której uczestnik bierze udział. Dzięki zdobytym umiejętnościom i doświadczeniu osoba z niepełnosprawnością może z większą łatwością odnaleźć się na otwartym bądź chronionym rynku pracy, jednak nie jest to częste zjawisko. Piotr Stanisławski podaje, że „z raportu PFRON wynika, że rocznie mniej niż 1 proc. uczestników Warsztatów znajduje pracę, mimo że prowadzą one treningi przygotowujące do zatrudnienia. Uczy się na nich, jak poszukiwać informacji o pracy, kompletować potrzebne dokumenty albo pisać życiorys. Niestety, tego typu zajęcia prowadzi tylko połowa WTZ"19. Z Raportu końcowego badania sytuacji Warsztatów Terapii Zajęciowej wynika, że „nieliczni uczestnicy WTZ są gotowi do pojęcia zatrudnienia. W zdecydowanej większości WTZ osoby posiadające kompetencje i motywację do podjęcia zatrudnienia stanowią wyjątek na tle całego grona uczestników jest ich mniej niż 25\%. Jednoznaczną chęć do podjęcia zatrudnienia

19 http://www.niepelnosprawni.pl/ledge/x/17455 (dostęp: 5.01.2016). 
Mateusz Szafrański - Rehabilitacja zawodowa...

w większości wyrażają jedynie uczestnicy 28\% WTZ"20. Jednak w tym samym Raporcie autorzy piszą, że „praktycznie wszystkie warsztaty terapii zajęciowej podejmują działania w zakresie aktywizacji zawodowej (98\%). Jednocześnie w zdecydowanej większości WTZ mają one bardzo ogólny wymiar i charakter, ograniczając się do kształtowania szeroko rozumianych postaw potrzebnych w pracy zawodowej"21. Zatem prawie wszystkie WTZ w Polsce prowadzą działania związane z podejmowaniem aktywności zawodowej osób z niepełnosprawnością, jednak wciąż nie odzwierciedla tego niski wskaźnik zatrudnienia tych osób. Warsztaty terapii zajęciowej tracą w obecnym kształcie kontrolę nad realizacją jednego z celów. Spełniają jedynie zadania związane z realizacją rehabilitacji społecznej. Niski wskaźnik zatrudnienia - $23 \% 22$, wskazuje natomiast na niepoprawność działania systemu rehabilitacji zawodowej. Skuteczność rehabilitacji zawodowej i efektywne podejmowanie pracy przez osoby z niepełnosprawnością należy rozpocząć od zmiany sposobu myślenia rady programowej i rozpoczęcia przez nich podejmowania zadań poradnictwa zawodowego i szkoleń zawodowych.

\section{Pracownik zakładu aktywności zawodowej}

Ustawa z dnia 27 sierpnia 1997 roku o rehabilitacji zawodowej i społecznej oraz zatrudnianiu osób niepełnosprawnych definiuje zakład aktywności zawodowej i stanowi podstawę prawną dla jego działalności. Według niniejszego dokumentu jest to zakład, w którym co najmniej 70\% z wszystkich zatrudnionych stanowią osoby z niepełnosprawnością $\mathrm{w}$ stopniu znacznym lub $\mathrm{w}$ stopniu umiarkowanym z współwystępującym autyzmem, niepełnosprawnością intelektualną

\footnotetext{
${ }^{20}$ A. Morysińska i in., Badanie sytuacji warsztatów..., op. cit., s. 8.

21 Ibid., s. 10.

22 Według Badania Aktywności Ekonomicznej Ludności (BAEL, 2014) wskaźnik zatrudnienia osób z niepełnosprawnością w wieku produkcyjnym wynosi $23 \%$. Wynik dotyczy wszystkich osób z każdym rodzajem niepełnosprawności. Wskaźnik zatrudnienia osób z niepełnosprawnością intelektualną jest zatem niższy od 23\%.
} 
lub chorobą psychiczną. W drugim przypadku konieczna jest opinia rady programowej WTZ, która uzasadnia kontynuowanie rehabilitacji zawodowej i podjęcie pracy w zakładzie pracy chronionej (Dz. U. 1997 Nr 123 poz. 776, art. 29). Zakład aktywności zawodowej mogą utworzyć gminy, powiaty, fundacje i stowarzyszenia, których zadaniem statutowym jest m.in. rehabilitacja społeczna i zawodowa (Dz. U. 1997 Nr 123 poz. 776, art. 29). W Polsce funkcjonuje 67 zakładów aktywności zawodowej, 6 w województwie kujawsko-pomorskim ${ }^{23}$. M. Zegarek uważa, że „celem działalności zakładów aktywności zawodowej jest stworzenie osobom niepełnosprawnym możliwości doskonalenia określonych umiejętności zawodowych co powinno umożliwić im podjęcie zatrudnienia na chronionym rynku pracy"24. Ułatwia również rehabilitację społeczną i zawodową oraz przygotowuje do samodzielnego życia ${ }^{25}$. Dariusz Opioła następująco przedstawia specyfikę pracy osób z niepełnosprawnością w ZAZ: „funkcjonowanie Zakładów Aktywności Zawodowej oparte jest na prowadzeniu działalności produkcyjnej i usługowej, które są wykonywane na normalnie przyjętych zasadach. Profil produkcji, rodzaj oferowanych usług i metody pracy w ZAZ powinny być ściśle dostosowane do określonych rodzajów niepełnosprawności zatrudnionych pracowników"26. Stanowiska pracy powinny być dostosowane do indywidualnych możliwości i potrzeb pracowników z niepełnosprawnością. Z Raportu Państwowego Funduszu Rehabilitacji Osób Niepełnosprawnych pt. „Zakłady Aktywności Zawodowej w 2013 r." wynika, że w Polsce najwięcej ZAZ prowadzi działalność gastronomiczną (w tym catering), natomiast najmniej placówek zajmuje się działalnością w zakresie pomocy społecznej27.

${ }^{23}$ Zakłady Aktywności Zawodowej w 2013 roku. Informacja z badania, Państwowy Fundusz Rehabilitacji Osób Niepełnosprawnych, styczeń 2014, www.pfron.org.pl/ download/1/3431/zaz2013.pdf (dostęp: 20.01.2016), s. 9.

24 M. Zegarek, Rola doradcy zawodowego..., op. cit., s. 141.

25 Ibid.

${ }^{26}$ D. Opioła, Znaczenie orzeczenia o stopniu niepełnosprawności $w$ poradnictwie zawodowym, [w:] Poradnictwo zawodowe $w$ rehabilitacji osób niepełnosprawnych, E. Wojtasik, M. Wolan-Nowakowska (red.), Warszawa 2012, s. 101.

27 Zakłady Aktywności Zawodowej..., op. cit., s. 9. 
Mateusz Szafrański - Rehabilitacja zawodowa...

Czas pracy pracownika ZAZ z orzeczoną niepełnosprawnością w stopniu umiarkowanym i znacznym wynosi 7 godzin dziennie i 35 godzin tygodniowo ${ }^{28}$. Pracownicy ZAZ z niepełnosprawnością w stopniu umiarkowanym i znacznym biorą udział w zajęciach rehabilitacyjnych nie mniej niż 60 minut każdego dnia. Czas ten można wydłużyć na wniosek służb rehabilitacyjnych zakładu do 120 minut na dzień (Dz. U. 2007 Nr 242 poz. 1776, art. 12). Pracownicy ZAZ z umiarkowanym lub znacznym stopniem niepełnosprawności, podobnie jak uczestnicy WTZ pracują w oparciu o indywidualny program rehabilitacji zawodowej i społecznej. Program opracowuje zespół programowy, składający się z pracowników zajmujących się działalnością rehabilitacyjno-obsługową. Następnie program jest zatwierdzany przez kierownika zakładu. Program uwzględnia: sprawności osoby z niepełnosprawnością niezbędne w pracy, dostosowanie miejsca pracy oraz oprzyrządowanie stanowiska pracy. Ostatni element programu stanowi opis przewidywanych, pozytywnych konsekwencji działań, które służą poprawie sprawności psychofizycznej, zaradności osobistej i funkcjonowania społecznego u osób zatrudnionych (Dz. U. 2007 Nr 242 poz. 1776, art. 13, p. 1-2). Zespół programowy przynajmniej raz $w$ roku dokonuje oceny efektów rehabilitacji zawodowej i społecznej. W wyniku osiągnięcia przez pracownika ZAZ z niepełnosprawnością odpowiedniego poziomu sprawności społeczno-zawodowej zespół programowy wraz z kierownikiem, współpracując z powiatowym urzędem pracy, opracowuje możliwości zatrudnienia u innego pracodawcy (Dz. U. 2007 Nr 242 poz. 1776, art. 13, p. 4-5). Może to być zatrudnienie na chronionym rynku pracy, bądź przy osiągnięciu wyższego poziomu samodzielności i sprawności społecznej oraz zawodowej, na otwartym rynku pracy, na takich samych warunkach jak pełnosprawni konkurenci. Według M. Zegarka pracownicy z niepełnosprawnością, zatrudnieni w ZAZ odbierają wynagrodzenie za wykonywaną pracę29.

\footnotetext{
${ }^{28} \mathrm{http}: / /$ idn.org.pl/sonnszz/gospodarka_zaz.htm (dostęp: 12.01.2016).

${ }^{29}$ M. Zegarek, Rola doradcy zawodowego..., op. cit., s. 142.
} 
Podsumowując rozważania dotyczące funkcjonowania ZAZ, można stwierdzić, że „propozycja aktywizacji zawodowej skierowana do osób z niepełnosprawnością intelektualną, jaką jest zatrudnienie w ZAZ-ach, jest dobrą i rokującą na przyszłość propozycją zmierzającą w kierunku ich zatrudnienia na otwartym rynku pracy"30. Wynika to z badań przeprowadzonych przez Główny Urząd Statyczny z osobami zatrudnionymi w ZAZ. Wiele $\mathrm{z}$ badanych podjęło pracę na otwartym rynku pracy, Centrach Integracji Społecznej lub w spółdzielniach socjalnych ${ }^{31}$.

\section{Podsumowanie}

Warsztaty terapii zajęciowej i zakłady aktywności zawodowej stanowią etap przejściowy dla osoby z niepełnosprawnością w drodze do zatrudnienia na chronionym bądź otwartym rynku pracy. Rehabilitacja zawodowa, realizowana w tych placówkach jest częścią rehabilitacji kompleksowej, jednak w warsztatach terapii nie jest realizowana, zaś w zakładach aktywności zawodowej realizowana w pewnym stopniu. Na samym początku, według M. Garbata należy przeprowadzić preorientację zawodową, za pomocą terapii zajęciowej w WTZ lub ZAZ ${ }^{32}$. Umożliwiłoby to rozpoznanie możliwości i predyspozycji pracownika z niepełnosprawnością już na początkowym etapie aktywizacji zawodowej. Etapy rehabilitacji zawodowej według S. Kowalika są całkowicie realizowane $\mathrm{w}$ ZAZ, natomiast $\mathrm{w}$ WTZ proces rehabilitacji zawodowej zatrzymuje się najczęściej na przygotowaniu do pracy, dzięki bezcelowemu udziałowi $\mathrm{w}$ terapii zajęciowej, nie prowadzącemu do zatrudnienia.

Podsumowując kwestie realizacji procesu rehabilitacji zawodowej w wybranych placówkach w Polsce, warto przytoczyć niemieckie rozwiązania, które umożliwiają realizację rehabilitacji zawodowej oso-

\footnotetext{
30 D. Wolska, Umiejętności życiowe..., op. cit., s. 66.

31 Ibid.

32 M. Garbat, Praca dla osób..., op. cit., s. 197.
} 
Mateusz Szafrański - Rehabilitacja zawodowa...

bom z niepełnosprawnością. W niemieckim systemie funkcjonują centra rehabilitacji zawodowej, dedykowane młodzieży i dorosłym z niepełnosprawnością. Centra świadczą usługi kompleksowej rehabilitacji, z naciskiem na rehabilitację zawodową, co skutkuje wysokim wskaźnikiem zatrudnienia osób z niepełnosprawnością (70\% zostaje zatrudnionych najpóźniej po roku). Innym rozwiązaniem w Niemczech są warsztaty, które są dostępne dla osób z najbardziej poważnymi w skutkach niepełnosprawnościami. Osoby zatrudnione w warsztatach posiadają status pracownika. Mogą podjąć staż, praktykę lub zatrudnienie $\mathrm{w}$ firmie zewnętrznej, mając taką samą pozycję jak uczestnik warsztatów ${ }^{33}$. Polski ustawodawca powinien wprowadzić zmodyfikowane rozwiązania $\mathrm{z}$ niemieckiego systemu aktywizacji zawodowej. Przyczyniłoby się to do efektywnego przygotowania osób z niepełnosprawnością do pełnienia ról zawodowych, osiągnięcia wyższego wskaźnika zatrudnienia wśród tej grupy społecznej i większej ich aktywności na otwartym rynku pracy.

\section{Bibliografia:}

Baczała D., Niepełnosprawność intelektualna a kompetencje społeczne, Wydawnictwo UMK, Toruń 2012.

Bańczyk P., Eichner M., Pasternak K., Tulaja J., Model aktywizacji osób bezrobotnych $z$ różnymi typami niepełnosprawności, Centrum Społecznego Rozwoju, Łaziska Górne 2015.

Ćwirynkało K., Osoby z głębszq niepełnosprawnościq intelektualnq, [w:] Rehabilitacja i edukacja osób z niepetnosprawnościq wielozakresowa, K. Ćwirynkało, C. Kosakowski (red.), Wyd. Adam Marszałek, Toruń 2012.

Gałecki P., Święcicki Ł., Kryteria diagnostyczne z DSM-5. Desk Reference, Wyd. Edra Urban \& Partner, Wrocław 2015.

33 P. Bańczyk i in., Model aktywizacji osób bezrobotnych z różnymi typami niepełnosprawności, Centrum Społecznego Rozwoju, Łaziska Górne 2015, s. 22-24. 
Garbat M., Praca dla osób z niepełnosprawnościami- wartość, rehabilitacja czy konieczność?, [w:] Labor czy opus? Socjopedagogiczne konteksty ludzkiej pracy, A. Dobrychłop, E. Kowalska, P. Prüfer (red.), Wyd. Uniwersytetu Zielonogórskiego, Zielona Góra 2012.

Informacja analityczna dotycząca sytuacji osób niepełnosprawnych na rynku pracy w IV kwartale 2014 r., Raport BAEL, www.niepelnosprawni.gov.pl (dostęp: 5.01.2016)..

Kott T., Zajęcia pozalekcyjne i terapia zajęciowa z osobami o obniżonej sprawności umysłowej, Wyd. Akademii Pedagogiki Specjalnej, Warszawa 2005.

Maciarz A., Mały leksykon pedagoga specjalnego, Wyd. Impuls, Kraków 2005.

Majewski T., MOP $w$ działaniach na rzecz rehabilitacji zawodowej i zatrudnienia osób niepełnosprawnych. Niepełnosprawni na rynku pracy, „Biuletyn Ośrodka Informacyjnego Rady Europy" 1997, nr 4.

Morysińska A. i in., Badanie sytuacji warsztatów terapii zajęciowej. Raport końcowy z badania, Wyd. Państwowy Fundusz Rehabilitacji Osób Niepełnosprawnych, Warszawa 2014.

Opioła D., Znaczenie orzeczenia o stopniu niepełnosprawności w poradnictwie zawodowym [w:] Poradnictwo zawodowe $w$ rehabilitacji osób niepełnosprawnych, E. Wojtasik, M. Wolan-Nowakowska (red.), Wyd. Akademii Pedagogiki Specjalnej, Warszawa 2012.

Sikorska A., Wielowymiarowa rehabilitacja osób niepełnosprawnych w warsztatach terapii zajęciowej [w:] Pedagogiczne, medyczne i ekonomiczne aspekty niepełnosprawności, R. Czepczarz, W. Duczmal, S. Śliwa (red.), Wyd. Wyższa Szkoła Zarządzania i Administracji, Opole 2013.

Wolska D., Umiejętności życiowe jako wyznacznik aktywizacji zawodowej dorosłych z głębszą niepełnosprawnościq intelektualną, Wydawnictwo Naukowe Uniwersytetu Pedagogicznego, Kraków 2015.

Zakłady Aktywności Zawodowej w 2013 roku. Informacja z badania, Państwowy Fundusz Rehabilitacji Osób Niepełnosprawnych, styczeń 2014, www.pfron.org.pl/download/1/3431/zaz2013.pdf (dostęp: 20.01.2016).

Zegarek M., Rola doradcy zawodowego w procesie rehabilitacji zawodowej osób niepełnosprawnych [w:] Kalbarczyk A., Ławniczak B., Magnuszewska-Otulak G, Zegarek M., Poradnictwo zawodowe dla osób niepełnosprawnych, Wyd. MPiPS, Warszawa 2009. 
Mateusz Szafrański - Rehabilitacja zawodowa...

\section{Akty prawne:}

Rozporządzenie Ministra Gospodarki, Pracy i Polityki Społecznej z dnia 25 marca 2004 r. w sprawie warsztatów terapii zajęciowej, Dz.U. 2004 Nr 63 poz. 587.

Rozporządzenie Ministra Pracy i Polityki Społecznej z dnia 14 grudnia 2007 r. w sprawie zakładów aktywności zawodowej, Dz. U. 2007 Nr 242 poz. 1776.

Ustawa z dnia 9 maja 1991 r. o zatrudnianiu i rehabilitacji zawodowej osób niepełnosprawnych, Dz. U. $1991 \mathrm{Nr} 46$.

Ustawa z dnia 27 sierpnia 1997 r. o rehabilitacji zawodowej i społecznej oraz zatrudnianiu osób niepełnosprawnych, Dz. U. 1997 Nr 123 poz. 776 z późn. zm. 